НАУКОВИЙ ВІСНИК

Scientific messenger of Lviv National University of
Veterinar Medicine and Biotechnologies
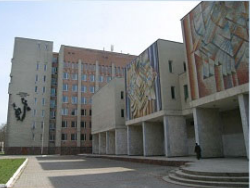

СЕРЯ: ВетеринаРнН НАYКИ

ERIES: VETERINARY SCIEN
Науковий вісник Аьвівського національного університету ветеринарної медицини та біотехнологій імені С.3. Гжицького. Серія: Ветеринарні науки

Scientific Messenger of Lviv National University of Veterinary Medicine and Biotechnologies. Series: Veterinary sciences

UDC 619:615.45:612.176:636

\title{
Influence of Metisevit Plus feed additive on the activity of the glutathione system of the body of bulls under conditions of man-caused load
}

\author{
S. O. Slobodian ${ }^{1}$, B. V. Gutyj ${ }^{1}$, S. H. Shalovylo ${ }^{1}$, T. S. Yaroshovych ${ }^{1}$, L. V. Kurylas ${ }^{2}$, O. I. Chajkovska ${ }^{2}$ \\ O. I. Stadnytska ${ }^{3}$, J. A. Garnazhenko ${ }^{4}$, V. L. Shnaider ${ }^{5}$, I. F. Bezpalyi ${ }^{6}$ \\ ${ }^{1}$ Stepan Gzhytskyi National University of Veterinary Medicine and Biotechnologies Lviv, Ukraine \\ ${ }^{2}$ State scientific research control institute of veterinary preparations and feed additives, Lviv, Ukraine \\ ${ }^{3}$ Institute of Agriculture of the Carpathian region of NAAS of Ukraine, v. Obroshino, Lviv region, Ukraine \\ ${ }^{4}$ Odessa Regional State Laboratory of the State Service of Ukraine for Food Safety and Consumer Protection, \\ Odessa, Ukraine \\ ${ }^{5}$ Polissia National University, Zhytomyr, Ukraine \\ ${ }^{6}$ Bila Tserkva National Agrarian University, Bila Tserkva, Ukraine
}

Article info

Received 06.10.2021

Received in revised form 08.11 .2021

Accepted 09.11.2021

Stepan Gzhytskyi National University of Veterinary Medicine and Biotechnologies Lviv,

Pekarska Str., 50, Lviv.

79010, Ukraine.

Tel.: +38-068-136-20-54

E-mail:bvh@ukr.net

State Scientific-Research Control Institute of Veterenary Medicinal

Products and Feed Additives,

Donetska Str., 11, Lviv,

79019, Ukraine.

Institute of Agriculture of the Carpathian region of the National Academy of Agrarian Sciences of Ukraine Grushevskogo Str. 5, Obroshino, Pustomytovsky District, Lviv Region, 81115, Ukraine.

Odessa Regional State Laboratory of the State Service of Ukraine for Food Safety and Consumer Protection, Odessa, Ukraine.

Polissia National Agroecological University, Korolyova Str., 39. Zhytomyr, 10025, Ukraine.

Bila Tserkva National Agrarian University, Pl. Soborna 8/1, Bila Tserkva, Kyiv region, 09117, Ukraine.
Slobodian, S. O., Gutyj, B. V., Shalovylo, S. H., Yaroshovych, T. S., Kurylas L. V., Chajkovska O. I., Stadnytska, O. I., Garnazhenko, J. A., Shnaider, V. L., \& Bezpalyi, I. F. (2021). Influence of Metisevit Plus feed additive on the activity of the glutathione system of the body of bulls under conditions of man-caused load. Scientific Messenger of Lviv National University of Veterinary Medicine and Biotechnologies. Series: Veterinary sciences, 23(104), 84-89. doi: 10.32718/nvlvet10414

Pollution of the environment with heavy metals due to artificial activities of the population has led to several problems for agricultural production. The work aims to study the influence of Metisevit Plus feed additive on the state of the glutathione system of the body of bulls under conditions of man-caused load. The research was conducted based on the private agricultural enterprise "Ukraine" Dubrovytsia district of Rivne region on 12 bulls six months old, Ukrainian black-and-white dairy breed, which was formed into two groups of 6 animals each: 1 group - control, bulls were on a standard diet; Group 2 - experimental, bulls were fed a feed additive "Metisevit plus" at a dose of $0.5 \mathrm{~g} / \mathrm{kg}$ of feed. According to studies, cadmium and lead load reduce the activity of the glutathione link in the antioxidant defense system of bulls. Feeding the Metisevit Plus feed additive to the bulls of the experimental group for 30 days helped increase the level of non-enzymatic and enzymatic activity of the glutathione system. A probable increase in the level of reduced glutathione was found on 30 and 40 days of the experiment, were compared with the control group of animals, it increased by 7.2 and $7.1 \%$, respectively. In the study of the activity of glutathione peroxidase and glutathione reductase, it was found that in these study periods they ranged from $35.7 \pm 1.61$ and $35.3 \pm$ $1.55 \mathrm{nmol} \mathrm{NADPH} / \mathrm{min}$ per $1 \mathrm{mg}$ of protein $(P \leq 0.01)$ and $1.67 \pm 0.041$ and $1.64 \pm 0.039 \mathrm{nmol} \mathrm{NADPH} / \mathrm{min}$ per $1 \mathrm{mg}$ of protein $(P \leq 0.001)$. Thus, studies on bulls indicate that the feed additive Metisevit Plus, when fed to bulls, under a load of cadmium and lead, contributed to the activation of the glutathione antioxidant defense system by increasing the level of enzymatic and non-enzymatic units. Our studies confirm the feasibility of using a feed additive, Metisevit Plus, to prevent lead-cadmium toxicosis.

Key words: Cadmium, Lead, bulls, feed additives, glutathione, glutathione peroxidase, glutathione reductase. 


\title{
Вплив кормової добавки “Метісевіт плюс" на активність глутатіонової системи організму бугайців за умов техногенного навантаження
}

\author{
С. О. Слободян ${ }^{1}$, Б. В. Гутий${ }^{1}$ С. Г. Шаловило ${ }^{1}$, Т. С. Ярошович ${ }^{1}$, Л. В. Курилас ${ }^{2}$, О. І. Чайковська ${ }^{2}$ \\ О. І. Стадницька ${ }^{3}$ Ю. А. Гарнаженко ${ }^{4}$ В. Л. Шнайдер ${ }^{5}$, І. Ф. Безпалий ${ }^{6}$
}

${ }^{1}$ Львівський національний університет ветеринарної медицини та біотехнологій імені С. 3. Гюицького, м. Львів, Україна

${ }^{2}$ Державний науково-дослідний контрольний інститут ветеринарних препаратів та кормових добавок, м. Львів, Украӥна

${ }^{3}$ Інститут сільського господарства Карпатського регіону НААН Украӥни, с. Оброшине, Львівська область, Україна

${ }^{4}$ Одеська регіональна державна лабораторія Державної служби Украӥни з питань безпечності харчових продуктів та захисту споживачів, м. Одеса, Україна

${ }^{5}$ Поліський національний університет, м. Житомир, Україна

${ }^{6}$ Білочерківський національний аграрний університет, м. Біла Церква, Україна

\begin{abstract}
Забруднення довкілля важкими металами внаслідок техногенної діяльності населення призвело до низки проблем для сільськогосподарського виробництва. Мета роботи - вивчити вплив кормової добавки “Метісевіт плюс" на стан глутатіонової системи організму бугайців за умов техногенного навантаження. Дослідження проводились на базі сільськогосподарського приватного підприємства "Украӥна" Дубровиџького району Рівненської області на 12 бугайцях шестимісячного віку, української чорно-рябоі молочної породи, які були сформовані у 2 групи по 6 тварин у кожній: 1 група - контрольна (K), бугайці перебували на стандартному рачіоні; 2 група - дослідна (Д), бугайчям згодовували кормову добавку “Метісевіт плюс" у дозі 0,5 г/кг комбікорму. Згідно з проведеними дослідженнями встановлено, що за кадмієвого і свинцевого навантаження знижується активність глутатіонової ланки системи антиоксидантного захисту оргнізму бугайців. Згодовування кормової добавки “Метісевіт плюс" бугайцям дослідної групи протягом 30 діб сприяло підвищенню рівня неензимної та ензимної активності глутатіонової системи. Вірогідне підвищення рівня відновленого глутатіону виявляли на 30 i 40 доби досліду, де порівняно з контрольною групою тварин він зріс на 7,2 $i$ 7,1\% відповідно. При дослідженні активності глутатіонпероксидази та глутатіонредуктази встановлено, шо у вказані періоди

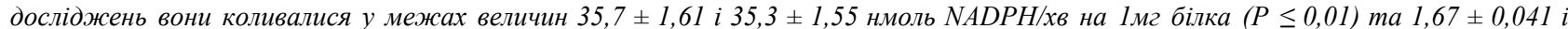
$1,64 \pm 0,039$ нмоль NADPH/xв на 1мг білка $(P \leq 0,001)$. Отже, проведені дослідження на бугайцях вказують на те, щзо кормова добавка "Метісевіт плюс" при згодовуванні бугайцям, за умов навантаження Кадмієм і Свинцем, сприяла активізаиї глутатіонової системи антиоксидантного захисту за рахунок підвищення рівня ензимної та неензимної ї̈ ланок. Проведені нами дослідження підтверджують доиільність застосування кормової добавки “Метісевіт плюс" для профілактики свиниево-кадмієвого токсикозу.
\end{abstract}

Ключові слова: Кадмій, Свинець, бугайці, кормові добавки, глутатіон, глутатіонпероксидаза, глутатіонредуктаза.

\section{Вступ}

В умовах сучасного техногенного забруднення навколишнього середовища екологічні проблеми, підвищення якості тваринницької продукції та ії харчової безпеки є важливим і актуальним питанням сьогодення (Ercal et al., 2001; Järup, 2003; Al-Azemi et al., 2010; Pratush et al., 2018; Vishchur et al., 2019; Piven et al., 2020; Yaroshevych et al., 2021).

Через погіршення екологічної ситуації одним із пріоритетних напрямів $\epsilon$ моніторинг важких металів у трофічному ланцюгу грунт - рослина - корм - тварина - продукція - людина. Дані забруднювачі швидко мігрують та накопичуються в компонентах біосфери (повітря, вода, грунт - рослини - тварини - людина), тим самим ускладнюють виробництво якісної сільськогосподарської продукції та негативно впливають на здоров'я людини (Rehman et al., 2018; Fryzova et al., 2018; Rahman \& Singh, 2019; 2020; Fu \& Xi, 2020). Тому необхідно вибирати таку систему ведення відповідної галузі тваринництва, яка б відповідала напрямку очікуваної продуктивності з метою одержання максимальної кількості високоякісної та благополучної у санітарному плані продукції (Fan et al., 2015).

Попередніми нашими дослідженнями було встановлено фоновий рівень окремих мікроелементів, Свинцю і Кадмію у різних кормах, які вирощувались для годівлі тварин у фермерському господарстві ім. Шевченка Здолбунівського району, СВК "Нива" Дубенського району та СП "Україна" Дубровицького району Рівненської області. Високий вміст Свинцю і Кадмію встановлено в кормах СВК "Нива" Дубенського району та СП "Україна" Дубровицького району. Одночасно виявлено значну відмінність у нагромадженні цих металів між різними видами кормів (Slivinska et al., 2019; Slobodian et al., 2020).

Найбільше Кадмію виявили у зернових та концкормах, де його концентрація перевищує максимально допустимий рівень у 1,39 (пшениця); 1,35 (жито); 1,23 (ячмінь) раза в СП "Україна" та відповідно 1,37; 1,20; 1,03 рази в СВК "Нива". Вище МДР було Кадмію в буряку кормовому та цукровому відповідно на 39 та $32 \%$.

Щодо вмісту Свинцю, то його найбільше було в соковитих кормах, а саме у гичці кормового буряка на $79,1 \%$ у СП "Україна", на $45,7 \%$ - в СВК "Нива"; зеленій масі трав природних пасовищ - відповідно на $69,3 \%$ та $76,4 \%$; зеленій масі викомішанки - на 69,2 $\%$ та $70,7 \%$ вище за максимально допустимий рівень.

У результаті проведених досліджень кормів встановлено високий вміст важких металів: Кадмію та Свинцю, що відповідно становить певну небезпеку для здоров’я тварин, якості їхньої продукції і в кінце- 
вому підсумку - здоров'я людини (Fregoneze et al., 1997; Albrecht et al., 2017). У зв'язку з цим є доцільним додаткове внесення антагоністів цих важких металів у раціони в спеціальних мінеральних добавках.

Особливий інтерес викликає стан системи антиоксидантного захисту організму тварин за умов різноманітних фізіологічних порушень і патологічних станів організму, в тому числі й тих, які викликаються токсичною дією важких металів (Gutyj et al., 2016; 2017; 2019; 2021). Згідно 3 даними літератури відомо, що важкі метали порушують баланс між утворенням в організмі прооксидантів та їх дезактивацією антиоксидантами, що, як наслідок, призводить до виникнення оксидаційного стресу (El-Shahat et al., 2009; Slobodian et al., 2019; Sall et al., 2020; Martyshuk et al., 2020; 2021; Renu et al., 2021; Nazaruk et al., 2021).

Дослідження саме глутатіонової системи за негативної дії важкими металами є актуальним не лише в контексті функціонування загальної антиоксидантної системи організму, а обумовлене також тим, що вона бере безпосередню участь у багатьох біохімічних механізмах детоксикації ліпофільних і гідрофільних ксенобіотиків (Stoyanovskyy et al., 2020; Vasylyev et al., 2021). Участь глутатіону і пов'язаних з ним систем у процесах біотрансформації та детоксикації ксенобіотиків визначає великою мірою стійкість організму до ïх токсичної дії (Ivankiv et al., 2019; Grymak et al., 2020).

Мета роботи - вивчити вплив кормової добавки “Метісевіт плюс" на стан глутатіонової системи організму бугайців за умов техногенного навантаження.

\section{Матеріал і методи досліджень}

Дослідження проводились на базі сільськогосподарського приватного підприємства "Україна" Дубровицького району Рівненської області на 12 бугайцях шестимісячного віку української чорно-рябої молочної породи, які були сформовані у 2 групи по 6 тварин у кожній:

1 група - контрольна (К), бугайці перебували на стандартному раціоні;

2 група - дослідна (Д), бугайцям згодовували кормову добавку “Метісевіт плюс" у дозі 0,5 г/кг комбікорму.

У даному господарстві було встановлено високий вміст Свинцю і Кадмію в кормах. Одночасно виявлено значну відмінність у нагромадженні цих металів між різними видами кормів. Найбільше Кадмію виявили у зернових та концкормах, де його концентрація перевищувала максимально допустимий рівень у 1,39 (пшениця); 1,35 (жито); 1,23 (ячмінь) раза. Щодо вмісту Свинцю, то його найбільше було в соковитих кормах, а саме у гичці кормового буряка на 79,1 \%; зеленій масі трав природних пасовищ - відповідно на
$69,3 \%$ та 76,4 \%; зеленій масі викомішанки - на 69,2 \% та 70,7 \% вище за максимально допустимий рівень.

Для проведення досліджень дотримувалися правил, обов'язкових при виконанні зоотехнічних дослідів щодо підбору та утримання тварин-аналогів у групах, технології заготівлі, використання й обліку спожитих кормів.

Усі маніпуляції з тваринами проводили відповідно до Європейської конвенції про захист хребетних тварин, які використовуються для експериментальних i наукових цілей (Official Journal of the European Union L276/33, 2010).

Для запобігання негативного впливу Кадмію та Свинцю на організм тварин на кафедрі фармакології та токсикології Львівського національного університету :етеринарної медицини та біотехнологій імені С. З. Гжицького було розроблено кормову добавку "Метісевіт плюс" на основі фенарону, вітамінів А і Е, метіоніну, Селену та Цинку.

Кров для аналізу брали 3 яремної вени на початку досліду, а також на 10, 20, 30 та 40 добу після згодовування кормової добавки "Метісевіт плюс".

Активність глутатіонпероксидази (К.Ф.1.11.1.9.) та та глутатіонредуктази (ГР) (К.Ф.1.6.4.2.) визначали за методом В. В. Лемешко і співавт. (1985); вміст відновленого глутатіону (ВГ) визначали за методом Е. Батлера (1963) (Vlislo, 2012).

Аналіз даних проводили за допомогою програми Statistica 6.0 (StatSoft Inc., США). Дані наведено в діаграмах у вигляді $\mathrm{x} \pm \mathrm{SD}(\mathrm{x} \pm$ стандартне відхилення). Відмінності між величинами у контрольній та експериментальній групах визначали за допомогою ANOVA, де відмінності вважалися достовірними при $\mathrm{P}<0.05$ (з урахуванням похибки Бонферроні).

\section{Результати та їх обговорення}

За результатами наших досліджень встановлено, що за кадмієвого і свинцевого навантаження знижується активність глутатіонової ланки системи антиоксидантного захисту. Так, у крові бугайців контрольної групи за умов навантаження важкими металами встановлено зниження рівня відновленого глутатіону до $29,58 \pm 0,55 \mathrm{мг} \%$.

Згодовування кормової добавки "Метісевіт плюс" бугайцям дослідної групи протягом 30 діб сприяло підвищенню рівня відновленого глутатіону протягом усього досліду. Так, на 10 добу досліду рівень показника у крові тварин дослідної групи зріс до 30,62 \pm 0,54 мг\%, тимчасом як у контрольної групи тварин він коливався у межах 29,59 \pm 0,49 мг\%. Вірогідне підвищення рівня відновленого глутатіону виявляли на 30 і 40 доби досліду, де порівняно 3 контрольною групою тварин він зріс на 7,6 і 7,1 \% відповідно (табл. 1). 


\section{Таблиця 1}

Рівень відновленого глутатіону у крові бугайців за умов свинцево-кадмієвого навантаження та дії кормової добавки "Метісевіт плюс", мг\% $(\mathrm{M} \pm \mathrm{m}, \mathrm{n}=6)$

\begin{tabular}{ccc}
\hline \multirow{2}{*}{ Тривалість досліду, доби } & \multicolumn{2}{c}{ Група тварин } \\
\cline { 2 - 3 } Вихідні дані & Контрольна & Дослідна \\
10 & $29,65 \pm 0,65$ & $29,63 \pm 0,58$ \\
20 & $29,59 \pm 0,49$ & $30,62 \pm 0,54$ \\
30 & $29,62 \pm 0,61$ & $31,11 \pm 0,63$ \\
40 & $29,60 \pm 0,59$ & $31,84 \pm 0,50^{*}$ \\
\hline
\end{tabular}

Проведеними дослідженнями активності окремих ензимів глутатіонової ланки системи антиоксидантного захисту у крові бугайців контрольної та дослідної груп встановлено, що активність глутатіонпероксидази та глутатіонредуктази на початку досліду коливалася у межах 29,4 $\pm 1,53$ і $28,9 \pm 1,45$ нмоль NADPH/хв на 1мг білка та 1,33 $\pm 0,040$ і $1,35 \pm 0,033$ нмоль NADPH/хв на 1мг білка (табл. 2 і 3 ).

При згодовуванні кормової добавки "Метісевіт плюс" бугайцям дослідної групи встановлено вірогід- не підвищення активності глутатіонпероксидази вже починаючи з 30 доби досліду, коли порівняно з контрольною групою тварин активність ензиму збільшилася на 23,5 \%. На 40 добу досліду активність глутатіонпероксидази у сироватці крові бугайців дослідної групи порівняно з попередньою добою дещо знизилася, однак порівняно 3 контрольною групою була вищою на $21,3 \%$.

\section{Таблиця 2}

Активність глутатіонпероксидази у сироватці крові бугайців за умов свинцево-кадмієвого навантаження та дії кормової добавки “Метісевіт плюс", нмоль NADPH/хв на 1мг білка $(\mathrm{M} \pm \mathrm{m}, \mathrm{n}=6)$

\begin{tabular}{ccc}
\hline \multirow{2}{*}{ Тривалість досліду, доби } & \multicolumn{2}{c}{ Група тварин } \\
\cline { 2 - 3 } & Контрольна & Дослідна \\
\hline Вихідні дані & $29,4 \pm 1,53$ & $28,9 \pm 1,45$ \\
10 & $29,0 \pm 1,36$ & $30,3 \pm 1,50$ \\
20 & $29,3 \pm 1,42$ & $33,4 \pm 1,29$ \\
30 & $28,9 \pm 1,51$ & $35,7 \pm 1,61^{* *}$ \\
40 & $29,1 \pm 1,46$ & $35,3 \pm 1,55^{*}$ \\
\hline
\end{tabular}

\section{Таблиця 3}

Активність глутатіонредуктази у сироватці крові бугайців за умов свинцево-кадмієвого навантаження та дії кормової добавки “Метісевіт плюс”, нмоль NADPH/хв на 1мг білка (M \pm m, n =6)

\begin{tabular}{ccc}
\hline \multirow{2}{*}{ Тривалість досліду, доби } & \multicolumn{2}{c}{ Група тварин } \\
\cline { 2 - 3 } & Контрольна & Дослідна \\
\hline Вихідні дані & $1,33 \pm 0,040$ & $1,35 \pm 0,033$ \\
10 & $1,31 \pm 0,034$ & $1,42 \pm 0,050^{*}$ \\
20 & $1,37 \pm 0,041$ & $1,51 \pm 0,047^{*}$ \\
30 & $1,34 \pm 0,037$ & $1,67 \pm 0,041^{* * *}$ \\
40 & $1,30 \pm 0,035$ & $1,64 \pm 0,039^{* * *}$ \\
\hline
\end{tabular}

При дослідженні активності глутатіонредуктази у сироватці крові бугайців дослідної групи встановлено, що при згодовуванні кормової добавки "Метісевіт плюс" активність даного ензиму вірогідно підвищується вже починаючи з 10 доби досліду, де відповідно вона коливалася у межах величин 1,42 $\pm 0,050$ нмоль NADPH/хв на 1мг білка, тимчасом як у контрольної групи вона відповідно становила $1,31 \pm 0,034$ нмоль NADPH/хв на 1мг білка. На 20 і 30 доби досліду активність глутатіонредуктази у сироватці крові бугайців дослідної групи зросла на 10,2 і 24,6 \% щодо контролю. На 40 добу досліду активність ензиму у крові дослідної групи залишалася високою і відповідно коливалася у межах 1,64 $\pm 0,039$ нмоль NADPH/хв на 1 мг білка.
Отже, проведені дослідження на бугайцях вказують на те, що кормова добавка "Метісевіт плюс" при згодовуванні бугайцям, за умов навантаження Кадмієм і Свинцем, сприяла активізації системи антиоксидантного захисту за рахунок підвищення рівня ензимної та неензимної ії ланок.

\section{Висновки}

Кормова добавка “Метісевіт плюс" при згодовуванні бугайцям, за умов навантаження Кадмієм і Свинцем, сприяє активуванню глутатіонової системи за рахунок підвищення рівня ії ензимної та неензимної ланок, зокрема: відновленого глутатіону - на 7,6 \% 
(Р < 0,05), глутатіонпероксидази - на 23,5\% $(\mathrm{P}<0,01)$ та глутатіонредуктази - на 24,6 \% (P < 0,001).

Проведені нами дослідження підтверджують доцільність застосування кормової добавки "Метісевіт плюс" для профілактики свинцево-кадмієвого токсикозу.

Відомості про конфлікт інтересів. Автори стверджують про відсутність конфлікту інтересів щодо їх вкладу та результатів досліджень.

\section{References}

Al-Azemi, M., Omu, F. E., Kehinde, E.O., Anim, J. T., Oriowo, M. A., \& Omu, A. E. (2010). Lithium protects against toxic effects of cadmium in the rat testes. Journal of Assisted Reproduction and Genetics, 27(8), 469-476. doi: 10.1007/s10815-010-9426-3.

Albrecht, A., Herbert, U., Miskel, D., Heinemann, C., Braun, C., Dohlen, S., Zeitz, J. O., Eder, K., Saremi, B., \& Kreyenschmidt, J. (2017). Effect of methionine supplementation in chicken feed on the quality and shelf life of fresh poultry meat. Poultry Science, 96(8), 2853-2861. doi: 10.3382/ps/pex071.

El-Shahat, A. E., Gabr, A., Meki, A. R., \& Mehana, E. S. (2009). Altered testicular morphology and oxidative stress induced by cadmium in experimental rats and protective effect of simultaneous green tea extract. International Journal of Morphology, 27(3), 757-764. doi: $10.4067 / \mathrm{S} 0717-95022009000300020$.

Ercal, N., Gurer-Orhan, H., \& Aykin-Burns, N. (2001). Toxic metals and oxidative stress part I: mechanisms involved in metal-induced oxidative damage. Current Topics in Medicinal Chemistry, 1(6), 529-539. doi: 10.2174/1568026013394831.

Fan, W., Wang, J., Wu, H., Lian, L., Du, S., \& Chen, L. (2015). Analysis of heavy metals monitoring results in food in Shaoxing in 2014. Wei Sheng Yan Jiu, 44(6), 922 927. URL: https://pubmed.ncbi.nlm.nih.gov/26738384.

Fregoneze, J. B., Marinho, C. A., Soares, T., Castro, L., Sarmento, C., Cunha, M., Gonzalez, V., Oliveira, P., Nascimento, T., Luz, C.P., Santana, Jr. P., DeOliveira, I.R., \& e-Castro-e-Silva, E. (1997). Lead $(\mathrm{Pb} 2+)$ and cadmium $(\mathrm{Cd} 2+)$ inhibit the dipsogenic action of central beta-adrenergic stimulation by isoproterenol. Brazilian Journal of Medical and Biological Research, 30(3), 419-423. doi: 10.1590/S0100879X1997000300018.

Fryzova, R., Pohanka, M., Martinkova, P., Cihlarova, H., Brtnicky, M., Hladky, J., \& Kynicky, J. (2018). Oxidative Stress and Heavy Metals in Plants. Reviews of Environmental Contamination and Toxicology, 245, 129-156. doi: 10.1007/398 20177.

Fu, Z., \& Xi, S. (2020). The effects of heavy metals on human metabolism. Toxicol Mech Methods, 30(3), 167-176. doi: 10.1080/15376516.2019.1701594.

Grymak, Y., Skoromna, O., Stadnytska, O., Sobolev, O., Gutyj, B., Shalovylo, S., Hachak, Y., Grabovska, O., Bushueva, I., Denys, G., Hudyma, V., Pakholkiv, N., Jarochovich, I., Nahirniak, T., Pavliv, O., Farionik, T., \& Bratyuk, V. (2020). Influence of "Thireomagnile" and "Thyrioton" preparations on the antioxidant status of pregnant cows. Ukrainian Journal of Ecology, 10(1), 122-126. doi: 10.15421/2020_19

Gutyj, B. V., Murs'ka, S. D., Gufrij, D. F., Hariv, I. I., Levkivs'ka, N. D., Nazaruk, N. V., Gajdjuk, M. B., Pryjma, O. B., Bilyk, O. Ja., \& Guta, Z. A. (2016). Influence of cadmium loading on the state of the antioxidant system in the organism of bulls. Visnyk of Dnipropetrovsk University. Biology, ecology, 24(1), 96-102. doi: 10.15421/011611.

Gutyj, B., Stybel, V., Darmohray, L., Lavryshyn, Y., Turko, I., Hachak, Y., Shcherbatyy, A., Bushueva, I., Parchenko, V., Kaplaushenko, A., \& Krushelnytska, O. (2017). Prooxidant-antioxidant balance in the organism of bulls (young cattle) after using cadmium load. Ukrainian Journal of Ecology, 7(4), 589-596. URL: https://www.ujecology.com/articles/prooxidantantioxid ant-balance-in-the-organism-of-bulls-young-cattleafter-using-cadmium-load.pdf.

Gutyi, B., Ostapiuk, A., Kachmar, N., Stadnytska, O., Sobolev, O., Binkevych, V. Petryshak, R., Petryshak, O., Kulyaba, O., Naumyuk, A., Nedashkivsky, V., Nedashkivska, N., Magrelo, N., Golodyuk, I., Nazaruk, N., \& Binkevych, O. (2019). The effect of cadmium loading on protein synthesis function and functional state of laying hens' liver. Ukrainian Journal of Ecology, 9(3), 222-226. URL: https://www.ujecology.com/articles/the-effect-ofcadmium-loading-on-protein-synthesis-function-andfunctional-state-of-laying-hens-liver.pdf.

Gutyj, B. V., Ostapyuk, A. Y., Sobolev, O. I., Vishchur, V. J., Gubash, O. P., Kurtyak, B. M, Kovalskyi, Y. V., Darmohray, L. M., Hunchak, A. V., Tsisaryk, O. Y., Shcherbatyy, A. R., Farionik, T. V., Savchuk, L. B., Palyadichuk, O. R., \& Hrymak, K. (2019). Cadmium burden impact on morphological and biochemical blood indicators of poultry. Ukrainian Journal of Ecology, 9(1), 236-239. URL: $\quad$ https://www.ujecology.com/articles/cadmiumburden-impact-on-morphological-and-biochemical-bloodindicators-of-poultry.pdf.

Gutyj, B., Khariv, I., Khalak, V., Khariv, M., Vasiv, R., Leskiv, Kh., Martyshuk, T., \& Guta, Z. (2021). The effect of liposomal drug "Butaintervit" on the activity of the t-system of cellular immunity of rats under oxidative stress. Colloquium-journal, 22(109), 14-18. doi: 10.24412/2520-6990-2021-22109-14-18.

Ivankiv, M., Kachmar, N., Mazurak, O., \& Martyshuk, T. (2019). Hepatic protein synthesis and morphological parameters in blood of rats under oxidative stress and action of feed additive "Butaselmevit-plus". Ukrainian Journal of Ecology, 9(4), 628-633. URL: https:/www.ujecology.com/articles/hepatic-proteinsynthesis-and-morphological-parameters-in-blood-ofrats-under-oxidative-stress-and-action-of-feedadditi.pdf.

Järup, L. (2003). Hazards of heavy metal contamination. British Medical Bulletin, 68, 167-182. doi: $10.1093 / \mathrm{bmb} / \operatorname{ldg} 032$

Martyshuk, T. V., Gutyj, B. V., Zhelavskyi, M. M., Midyk. S. V., Fedorchenko, A. M., Todoriuk, V. B., Nahirniak, T. B., Kisera, Ya. V., Sus, H. V., Chemerys, V. A., Levkivska, N. D., \& Iglitskej, I. I. (2020). 
Effect of Butaselmevit-Plus on the immune system of piglets during and after weaning. Ukrainian Journal of Ecology, 10(2), 347-352. doi: 10.15421/2020_106.

Martyshuk, T. V., Gutyj, B. V., Leskiv, Kh. Ya., Semaniuk, N. V., \& Shnaider, V. L. (2021). The effect of the liposomal drug "butaselmevit" on the enzymatic and nonenzymatic part of the glutatoin system of the blood of rats under oxidative stress. Colloquium-journal, 12(99), 16-19. URL: https://elibrary.ru/item.asp?id=46447356.

Nazaruk, N. V., Gutyj, B. V., Gufrij, D. F., Leskiv, Kh. Ya., Ivashkiv, R. M., \& Martyshuk, T. V. (2021). The effect of methyphen and vitamix se on the level of products of bull lipid peroxide oxidation under nitratecadmium load. Colloquium-journal, 7(94), 1618. doi:10.24412/2520-6990-2021-794-16-18.

Nazaruk, N. V., Gufrij, D. F., Gutyj, B. V., Hachak, Yu. R., Leskiv, Kh. Ya., \& Shnaider, V. L. (2021). The activity of oxidoreductases of bulls serum under nitratecadmium loading. Colloquium-journal, 12(99), 20-23. URL: https://elibrary.ru/item.asp?id=46447357.

Piven, O. T., Khimych, M. S., Salata, V. Z., Gutyj, B. V., Naidich, O. V., Skrypka, H. A., Koreneva, Z. B., Dvylyuk, I. V., Gorobey, O. M., \& Rud, V. O. (2020). Contamination of heavy metals and radionuclides in the honey with different production origin. Ukrainian Journal of Ecology, 10(2), 405-409. URL: https://www.ujecology.com/articles/contmination-ofheavy-metals-and-radionuclides-in-the-honey-withdifferent-production-origin.pdf.

Pratush, A., Kumar, A., \& Hu, Z. (2018). Adverse effect of heavy metals ( $\mathrm{As}, \mathrm{Pb}, \mathrm{Hg}$, and $\mathrm{Cr}$ ) on health and their bioremediation strategies: a review. International Microbiology, 21(3), 97-106. doi: 10.1007/s10123018-0012-3.

Rahman, Z., \& Singh, V. P. (2019). The relative impact of toxic heavy metals (THMs) (arsenic (As), cadmium (Cd), chromium (Cr)(VI), mercury (Hg), and lead $(\mathrm{Pb})$ ) on the total environment: an overview. Environmental Monitoring and Assessment, 191(7), 419. doi: 10.1007/s10661-019-7528-7.

Rahman, Z., \& Singh, V. P. (2020). Bioremediation of toxic heavy metals (THMs) contaminated sites: concepts, applications and challenges. Environmental Science and Pollution Research, 27(22), 2756327581. doi: 10.1007/s11356-020-08903-0.

Rehman, K., Fatima, F., Waheed, I., \& Akash, M. S. H. (2018). Prevalence of exposure of heavy metals and their impact on health consequences. Journal of Cellular Biochemistry, 119(1), 157-184. doi: 10.1002/jcb.26234.

Renu, K., Chakraborty, R., Myakala, H., Koti, R., Famurewa, A.C., Madhyastha, H., Vellingiri, B., George, A., Valsala Gopalakrishnan, A. (2021). Molecular mechanism of heavy metals (Lead, Chromium, Arsenic, Mercury, Nickel and Cadmium) - induced hepatotoxicity - A review. Chemosphere, 271, 129735. doi: 10.1016/j.chemosphere.2021.129735.

Sall, M. L., Diaw, A. K. D., Gningue-Sall, D., Aaron, S. E., \& Aaron, J.-J. (2020). Toxic heavy metals: impact on the environment and human health, and treatment with conducting organic polymers, a review. Envi- ronmental Science and Pollution Research, 27(24), 29927-29942. doi: 10.1007/s11356-020-09354-3.

Slivinska, L. G., Shcherbatyy, A. R., Lukashchuk, B. O., Zinko, H. O., Gutyj, B. V., Lychuk, M. G., Chernushkin, B. O., Leno, M. I., Prystupa, O. I., Leskiv, K. Y., Slepokura, O. I., Sobolev, O. I., Shkromada, O. I., Kysterna, O. S., \& Musiienko, O. V. (2019). Correction of indicators of erythrocytopoesis and microelement blood levels in cows under conditions of technogenic pollution. Ukrainian Journal of Ecology, 9(2), 127-135. URL: https://www.ujecology.com/articles/correctionof-indicators-of-erythrocytopoesis-and-microelementblood-levels-in-cows-under-conditions-of-technogenicpoll.pdf.

Slobodian, S. O., Gutyj, B. V., \& Leskiv, K. Y. (2019). The level of lipid peroxidation products in the rats blood under prolonged cadmium and lead loading. Ukrainian Journal of Veterinary and Agricultural Sciences, 2(3), 15-18. doi: 10.32718/ujvas2-3.04

Slobodian, S., Gutyj, B., Gufriy, D., Hnativ, P., \& Murska, S. (2020). The effect of sodium selenite and feed additive "Metisevit plus" on the proteinsynthesizing function and functional state of the liver of rats under prolonged cadmium and lead loading. Scientific Messenger of LNU of Veterinary Medicine and Biotechnologies. Series: Veterinary Sciences, 22(100), 54-59. doi: 10.32718/nvlvet10010.

Stoyanovskyy, V., Usenko, S., Shostya, A., Kuzmenko, L., Slynko, V., \& Tenditnyk, V. (2020). Hormonal regulation of prooxidant-antioxidant homeostasis in gilts. Ukrainian Journal of Veterinary and Agricultural Sciences, 3(3), 39-43. doi: 10.32718/ujvas3-3.08.

Vasylyev, D., Priimenko, B., Aleksandrova, K., Mykhalchenko, Y., Gutyj, B., Mazur, I., Magrelo, N., Sus, H., Dashkovskyy, O., Vus, U., \& Kamratska, O. (2021). Investigation of the acute toxicity of new xanthine xenobiotics with noticeable antioxidant activity. Ukrainian Journal of Ecology, 11(1), 315-318. doi: 10.15421/2021_47.

Vishchur, V. Y., Gutyj, B. V., Nischemenko, N. P., Kushnir, I. M., Salata, V. Z., Tarasenko, L. O., Khimych, M. S., Kushnir, V. I., Kalyn, B. M., Magrelo, N. V., Boiko, P. K., Kolotnytskyy, V. A., Velesyk ,T., Pundyak, T. O., \& Gubash, O. P. (2019). Effect of industry on the content of fatty acids in the tissues of the honey-bee head. Ukrainian Journal of Ecology, 9(3), 174-179. URL: https://www.ujecology.com/articles/effect-ofindustry-on-the-content-of-fatty-acids-in-the-tissues-ofthe-honeybee-head.pdf.

Vlislo, V. V. (2012). Laboratorni metody doslidzhen u biolohii, tvarynnytstvi ta veterynarniy medytsyni [Laboratory methods of research in biology, animal husbandry and veterinary medicine]. Spolom, Lviv (in Ukrainian).

Yaroshevych, N. B., Gutyj, B. V., Hrymak, O. Ya., Kushnir, L. P., Kalaitan, T. V., Kondrat, I. Y., \& Shevchuk, O. O. (2021). The state of environmental taxation in Ukraine and the main directions of reform. Ukrainian Journal of Ecology, 11(1), 350-359. doi: 10.15421/2021_52. 